\title{
HEALTH PROFESSIONS STUDENTS' INTERPROFESSIONAL EXPERIENCES ON A RURAL LEARNING PLATFORM
}

\author{
A. Joubert* \\ School of Nursing \\ e-mail: gnvkaj@ufs.ac.za

\section{R. W. Botha*} \\ Office of the Dean \\ e-mail: BothaRW@ufs.ac.za

\section{H. Morgan*} \\ School of Allied Health Professions \\ e-mail: MorganH@ufs.ac.za
}

\section{Wilmot}

Office of the Dean

e-mail:WilmotM@ufs.ac.za

\section{T. Hagemeister*}

Clinical unit: Family medicine

e-mail: HagemeisterDT@ufs.ac.za

${ }^{*}$ Faculty of Health Sciences

University of the Free State

Bloemfontein, South Africa

\section{ABSTRACT}

A Faculty of Health Sciences launched a rural collaborative learning platform to cultivate interprofessional key competencies and to improve health outcomes. The purpose of the study was to describe health sciences students' experiences of a rural collaborative learning platform. Health professions students created digital stories reflecting on their collaborative learning experiences. Purposive sampling resulted in 23 submissions. Qualitative analysis of content identified themes and categories. Three themes, namely, metaphor, critical consciousness and professional socialisation, were identified. The metaphor categories, Journey, Setting world ablaze, Water, and Puzzle, represent students' desire to use visual cues to describe their experiences. Transformation, Personal development and Empathy signified critical consciousness. Collaborative practice, Values, Reflective practice, and Key competencies relate to professional socialisation. The researchers gained understanding of students' experiences on a rural collaborative learning platform. Through digital stories, students became aware of 
professional interdependency, which linked their experiences to key interprofessional competencies

Keyword: digital storytelling, Interprofessional Education (IPE), key competencies, student learning

\section{INTRODUCTION}

Globally, and in developing countries, in particular, teaching and learning innovations that challenge the boundaries of traditional teaching practices and the achievement of interprofessional graduate competencies, are called for (Reeves, Goldman and Oandasan 2007). A Faculty of Health Sciences established a rural learning platform to facilitate a communitybased Interprofessional Education (IPE) programme aligned with the South African national vision to promote access to quality healthcare (DoH 2017). In this context, a rural interprofessional learning platform refers to a new, rural learning and practice environment, established to create tailored interprofessional learning and collaborative practice opportunities for health professions students (Reeves, Goldman and Oandasan 2007).

Interprofessional learning and collaboration involves complex, dynamic interactions between academic facilitators, students and communities. Strategic to this faculty's IPE programme is the acquisition of key interprofessional competencies through a variety of shared learning opportunities. Reflective assessment, in the form of digital storytelling, encapsulates the learning experiences and acquired competencies. The Faculty of Health Sciences is committed to refining and defining the new programme, thereby facilitating quality assurance. This commitment requires investigation of the experiences of health professions students involved in the IPE programme.

\section{LITERATURE REVIEW}

IPE, introduced in 1960 as an approach that challenges traditional teaching practices, has gained momentum since 1970. This approach was strengthened by the World Health Organization (WHO) through the publication of several reports (Reeves 2016; Elsevier 12/2013; Treadwell and Havenga 2013; Thistlethwaite 2012). The WHO's (2010) definition of IPE, which is acknowledged by numerous publications (Reeves 2016; Thistlethwaite 2012; Anderson and Kinnair 2016), states that "[i]nterprofessional education occurs when two or more professionals learn about, from and with each other to enable effective collaboration an improve health outcomes" (WHO 2010). However, IPE is more than simply, "working together and working well with others outside the traditional care circle" (Elsevier 2012/13). At its core, key interprofessional competencies, such as values applicable to interprofessional practice, 
acknowledging own roles and those of other professionals, interprofessional communication, teams and teamwork, and person-centred care, form the foundation of learning to achieve optimal collaborative healthcare (Schwindt et al. 2017; Elsevier 2012/13). Learning opportunities incorporate these competencies across the learning continuum, through orientation (introductory), immersion (interprofessional placement), reflection (personalisation of experience) and, ultimately, acquisition of competence. Five underlying concepts, namely, sharing, partnership, power, interdependency and process, define collaboration (University of Toronto n.d.).

Professional bodies and academic institutions responded to the WHO 2010 report by proposing the Framework for Action on Interprofessional Education and Collaborative Practice (D'Amour et al. 2005; Mahboobeh et al. 2016). Professional bodies mandated, “interprofessional education in health professions programs" (Ratka, Zorek and Meyer 2017, 1). Several accreditation standards that are stated by the Accreditation Council for Pharmacy Education, among which, standards for curriculum design, assessment of students' readiness and preparedness for collaboration accentuate the importance of interprofessional education. Models to structure IPE competencies in curricula are freely available (Ratka, Zorek and Meyer 2017).

Educationists realised that traditional approaches that encourage "discipline specific" teaching and learning will not develop the attributes required by healthcare professionals (Mahboobeh et al. 2016). Consequently, academic groups reacted in various ways to address IPE. Strategies to incorporate key interprofessional competencies, such as the ability to collaborate and communicate effectively, and to provide integrated healthcare into health professions curricula, were agreed on during a summit hosted in 2002 by the Institute of Medicine (MacDonnell, George and Misto 2012). A few years later, the University of Rhode Island's College of Pharmacy developed interdisciplinary modules and interactive learning activities, involving groups of nursing and pharmacy students (MacDonnell, George and Misto 2012). Initiatives by various partners to establish more collaboration and partnerships for student learning followed. Eventually, an "expanded, team-based, educational program", and a tailored curriculum were developed (MacDonnell, George and Misto 2012, 277).

Other initiatives include the Daniels IPE Scholars Program, which aims to promote collaboration between medicine, nursing and pharmacy students. This year-long course includes 16 seminars, six home visits with a health mentor, and a community service project. Students apply to participate in the pre-licensure program (John Hopkins School of Nursing 2012). Sevin, Hale, Brown and McAuley (2016) mention that service-learning is an option to address interprofessional learning in real-life settings. The service-learning course aims to 
prepare students to practice and collaborate in a free, student-run clinic. Workshops provide students with opportunities to reflect on and discuss their experiences. Modes of delivery include lectures, small- and large-group activities, reflection, and role-play.

Closer to home, the Faculty of Health Sciences at the University of Cape Town, South Africa, responded innovatively to address students' educational readiness and to ensure that exit-level standards for clinical competency are upheld. Revised undergraduate curricula reflect inclusiveness, participation, social responsiveness and social justice. Redefined graduate characteristics include responsiveness to the diverse health needs of the country (Hartman et al. 2012). Acknowledging international and national initiatives to enhance collaborative learning facilitates the implementation of rural-based, multi-professional teams (Hartman et al. 2012).

Another South African institution, Stellenbosch University's Faculty of Medicine and Health Sciences, together with several stakeholders, opted for a unique approach to address a rural community's needs; to ensure optimal training of students; and to become an "engaged institution". By establishing the Ukwanda Center of Rural Health, they paved the way for the Ukwanda Rural Clinical School (Fish et al. 2015, 79). Since 2011, final-year medical students complete their training in this rural environment. Physiotherapy, dietetics and post-basic primary healthcare nursing students joined in 2012 to form an interprofessional team. These interprofessional teams, accompanied by resident community care workers, screen households in order to establish a community profile in relation to social, environmental and health-related issues. Interest in this teaching and learning approach sparked involvement by other undergraduate divisions (Fish et al. 2015). Services, such as family planning, rehabilitative care and student-driven home-based care, became available and accessible to the community (Fish et al. 2015). In addition to providing healthcare services, students became involved, and they had more opportunities to become skilled practitioners (Fish et al. 2015).

An interprofessional programme at the University of Pretoria, South Africa, was developed to promote interprofessional functioning and effective teamwork amongst undergraduate final-year students in occupational, speech and physiotherapy. To address the aim of a multi-method study, the researcher selected a care centre in a community to implement the programme. Students reflected positively on "co-ordination, contribution, mutual support, effort, cohesion, effectiveness, efficiency and work satisfaction" (Van Wyk 2017, iii).

The Nelson Mandela University (NMU), South Africa, launched four new developments, one of which was an IPE initiative. Students from 10 disciplines in the Faculty of Health Sciences collaborate in various under-resourced communities, with the aim of enhancing comprehensive primary healthcare services (NMU n.d.).

The School of Audiology, Occupational Therapy and Speech-Language Pathology at 
South Africa's University of KwaZulu-Natal implemented a model that exposes first-and fourth-year students to IPE. With the aim of promoting dialogue between professionals, and developing skills for functioning in a transdisciplinary healthcare environment, students work in various communities (Flack 2011).

The Faculty of Health Sciences at the University of the Free State endorses value and role clarification, person-centred care, team functioning and interprofessional communication as key interprofessional competencies students have to achieve on an rural collaborative learning platform. The structured IPE programme provides many opportunities, embedded in each carefully selected activity, to attain these competencies. In support of existing healthcare services, health professions students screen learners at high schools in two towns; complete screening of patients diagnosed with diabetes mellitus, and provide follow-up care of all diabetes mellitus patients during home-based care visits. These students also facilitate a youth leadership programme and a lifestyle group for diabetes mellitus patients. As part of the programme, students are also involved in electronic capturing of data and preparing referral letters and forms. Students and facilitators discuss experiences and healthcare issues during scheduled reflection sessions. Digital stories of the experiences of student groups are the only form of assessment used in the IPE programme. Facilitators involved in innovative teaching and learning utilise resources that go beyond traditional teaching practices, and present the material in a manner and at a level that makes it possible for students to collaborate and to achieve key interprofessional competencies required for effective practice.

Efforts to implement IPE at South African institutions of higher learning, as discussed above, started a national educational revolution that was soon recognised by the South African Association of Health Educationalists (SAAHE). This representative association issued a consensus statement that declared that decentralised training in the health professions acknowledges the need to change health professions education through a decentralised approach (SAAHE 2017). Health professionals and educationists from various disciplines and higher education institutions also agreed on the need to develop a national consensus approach to addressing decentralised education, and developing a shared vision and a framework to guide the implementation of the proposed approach to health education (SAAHE 2017).

Contrary to studies on the development of IPE programmes and different modes of delivery, few studies have been done on assessment of the acquisition of knowledge by health professionals, and changing their attitudes or behaviour (Thistlethwaite 2012). Unfortunately, evidence related to the effectiveness and impact of IPE is lacking (Thistlethwaite 2012). Assessment of the effectiveness of IPE is jeopardised by a number of factors, including programmes and modules offering IPE, and the selection and variety of collaborative learning 
opportunities (Thistlethwaite 2012). Thistlethwaite $(2012,62)$ makes an important statement: "From an education perspective, there is a need to ensure constructive alignment among the aim of, the activities for and the assessment of IPE".

Reeves, Goldman and Oandasan $(2007,2)$ identifies three gaps related to IPE assessment, namely, comparing the effectiveness of IPE interventions to other profession-specific initiatives; examining "processes relating to the IPE and practice changes" by means of a diversity of studies that include qualitative aspects, and determining the cost effectiveness of these initiatives. The fact that surveys are a very popular choice did not seem to fill the gaps (Treadwell and Havenga 2013).

IPE advocates do not avoid addressing the gaps caused by the challenge of assessing students' IPE competencies. Different approaches, frameworks, strategies or modes of assessment reflect a commitment to determining the minimum standard for IPE assessment (Anderson and Kinnair 2016). Both summative and formative assessment of IPE are suggested (Anderson and Kinnair 2016). Assessments that include portfolios and group and peer assessments are proposed as modes suitable for assessing teamwork and collaboration (Thistlethwaite 2012). Objective structured clinical and written examinations for assessing knowledge also seem to be popular methods (Anderson and Kinnair 2016).

Notwithstanding the type of assessment used, assessment of IPE competencies should meet the requirements of professional bodies (Anderson and Kinnair 2016). However, Anderson and Kinnair (2016) are concerned that assessment of interprofessional learning is overshadowed by profession-specific content and requirements. The authors claim that governing bodies need to revise their requirements to include interprofessional learning and competencies.

The assessment of the impact of IPE on indicators of collaborative practice, such as efficiency, teamwork and self-reported outcomes, and on patient-related outcomes, such as satisfaction, disease incidence and complication rates, remains questionable too (Reeves 2016; Treadwell and Havenga 2013; Cox et al. 2016; Brashers et al. 2015). Assessing the impact of IPE requires carefully selected or tailored tools that are valid and reliable. Furthermore, measurement tools should have strong psychometric properties (Schwindt et al. 2017).

Schwindt et al. (2017) assessed the validity and reliability of the Interprofessional Collaborative Competency Attainment Survey, (ICCAS) an instrument that measures current IPE competencies. The ICCAS was used to assess self-reported health professions students attitudes health professions students towards IPE, and students' perceived ability to engage in collaborative practice. Schwindt et al. (2017) confirm that the ICASS met the requirements for internal reliability within the context of their study. Within the context of the current study, the 
experiences of health professions students on an rural interprofessional learning platform culminated in the students presenting digital stories.

\section{PURPOSE STATEMENT}

The purpose of the study was to describe if health professions students' learning experiences developed key interprofessional competencies. Strengthening healthcare reform requires healthcare professionals who are competent to provide integrated care using innovative means and educational strategies, resources and technology (Elsevier 2012/13; De Castro Barbosa Mello, Alves and Lemos 2015-2027).

\section{RESEARCH QUESTION}

Do the learning experiences of health professions students on an rural learning platform develop key interprofessional competencies?

\section{MATERIALS AND METHODS}

Fourth-year health professions students $(\mathrm{N}=324)$, divided into teams representing different healthcare professions, followed a newly developed, structured IPE programme. Vital to the programme, which had been designed by IPE experts, was the achievement of key interprofessional competencies through a variety of learning experiences. The key interprofessional competencies endorsed by the Faculty of Health Sciences are (a) role and value clarification, (b) person-centred care, (c) team functioning and (d) interprofessional communication. Learning, aided by continuous reflection on experiences, strengthened the acquisition of these key competencies. Post-placement assessment using digital storytelling encapsulated the learning experiences and acquired competencies.

\section{Research design}

A qualitative descriptive design was used to explore themes and patterns embedded in the digital story narratives (Du Plooy-Cilliers, Davis and Bezuidenhout 2014).

\section{Research technique}

The health professions students compiled digital stories depicting their experiences through 10 images and a five-minute narrative. Digital storytelling combines narration with the use of new media technology, such as podcasts, videos, blogs, and social networks (Lambert 2013). Tools through which students share their experiences with others are increasing in number, diversity, 
and sophistication. Narratives are discourses for a definite audience, presented in a clear, sequential order that connect events in a meaningful way (Green and Walters n.d). Visual images can be used to tell stories and, in narrative pedagogy, as a way to illustrate themes (Green and Walters n.d). Art, photography, and narratives enhance affective learning in a specific domain, (Green and Walters n.d), and using these techniques in IPE induces abstract ideas and shared human experiences.

Crucial elements for successful storytelling are that the story should be personal and authentic; the story should address a dramatic question; the content should be engaging; include the narrator's voice and music to anticipate and emphasise the central elements of the narrative. The rule that "less is more" is followed, letting the audience work out implicit meanings and metaphors. The stories should create interaction with the audience and convey a concise rhythm.

\section{Unit of analysis}

The unit of analysis consisted of 27 digital stories developed by health professions students. Twenty-seven groups that consisted of 324 students created the digital stories. Purposive sampling selected 23 digital stories representing students from at least three professions. Four stories did not meet the inclusion criterion.

\section{Data gathering, analysis and trustworthiness}

Students completed a post-placement survey that also served as informed consent for the current study. The teams presented their digital stories to facilitators to conclude the interprofessional learning that had taken place over five days. After transcription, the eight steps proposed by Tesch (cited in Creswell 2014) guided the content analysis of narratives. To ensure trustworthiness, the researchers considered credibility, transferability, dependability and confirmability throughout the description of information.

\section{Ethical considerations}

The institution gave permission and ethical clearance to conduct the research (HREC No. 201/2016). The researchers maintained the ethical principles of beneficence, respect for human dignity and justice in every aspect of the study.

\section{FINDINGS}

Three themes presented during analysis of the transcripts of the digital stories. The three themes are conceptual metaphor, critical consciousness and interprofessional socialisation. Table 1 
presents the themes and the categories and definitions best aligned with the purpose of this study, as justified by Creswell's analytical spiral step Number 7: Testing the emergent understandings (Creswell 1998).

Table 1: Themes, categories and definitions depicting students' experiences on an rural collaborative learning platform

\begin{tabular}{|c|c|c|c|}
\hline Theme & Definition* & Category & Definitions \\
\hline \multirow[t]{12}{*}{ Metaphor } & \multirow{12}{*}{$\begin{array}{l}\text { Using metaphors and } \\
\text { comparison to explain } \\
\text { shared IPE } \\
\text { experiences during the } \\
\text { week's placement }\end{array}$} & Journey & $\begin{array}{l}\text { Associating the IPE experience with } \\
\text { undertaking a journey (of change) }\end{array}$ \\
\hline & & $\begin{array}{l}\text { Setting world } \\
\text { ablaze }\end{array}$ & $\begin{array}{l}\text { Comparing the IPE experience to creating } \\
\text { a fire (of achievement) }\end{array}$ \\
\hline & & Water & $\begin{array}{l}\text { Comparing the way different professions } \\
\text { coming together to form a valuable merger } \\
\text { to the flow of water }\end{array}$ \\
\hline & & Puzzle & $\begin{array}{l}\text { Associating understand the complexities } \\
\text { associated with their IPE experience to a } \\
\text { completing a puzzle (with guidance) }\end{array}$ \\
\hline & & Tree & $\begin{array}{l}\text { Students indicate that they were planted } \\
\text { within the community during their } \\
\text { placement }\end{array}$ \\
\hline & & Travelers & $\begin{array}{l}\text { The week's placement was compared to } \\
\text { discovering new places and opportunities }\end{array}$ \\
\hline & & Frozen land & $\begin{array}{l}\text { The foreign Trompsburg environment } \\
\text { through which students had to travel to } \\
\text { reach their goal }\end{array}$ \\
\hline & & Windmill & $\begin{array}{l}\text { Students used the structure of a windmill to } \\
\text { illustrate the relationship between } \\
\text { community, healthcare and social well- } \\
\text { being }\end{array}$ \\
\hline & & Avengers & $\begin{array}{l}\text { Students described themselves as } \\
\text { superheroes coming together to achieve a } \\
\text { common goal }\end{array}$ \\
\hline & & Dr Seuss & $\begin{array}{l}\text { Students used anecdotes from Dr Suess } \\
\text { books to describe their experiences }\end{array}$ \\
\hline & & Adventure & $\begin{array}{l}\text { Students describe life in general and their } \\
\text { approach to the week in Trompsburg as an } \\
\text { adventure }\end{array}$ \\
\hline & & Flight & $\begin{array}{l}\text { The week's placement was compared to } \\
\text { taking a flight, with all the characteristics of } \\
\text { flight, to a specific destination }\end{array}$ \\
\hline \multirow[t]{8}{*}{$\begin{array}{l}\text { Critical } \\
\text { consciousness }\end{array}$} & \multirow{8}{*}{$\begin{array}{l}\text { To describe an } \\
\text { individual's critical } \\
\text { understanding of the } \\
\text { world and how } \\
\text { individual, social and } \\
\text { political circumstances } \\
\text { influence the } \\
\text { understanding of one's } \\
\text { reality }\end{array}$} & Praxis & $\begin{array}{l}\text { Opportunities to gain and apply clinical and } \\
\text { interprofessional proficiencies }\end{array}$ \\
\hline & & Transformation & $\begin{array}{l}\text { Dissonance is the impetus for affective, } \\
\text { cognitive and psychomotor development }\end{array}$ \\
\hline & & Challenges & $\begin{array}{l}\text { Barriers to addressing community } \\
\text { healthcare needs can be overcome } \\
\text { through student creativity }\end{array}$ \\
\hline & & $\begin{array}{l}\text { Professional } \\
\text { socialisation } \\
\text { development }\end{array}$ & $\begin{array}{l}\text { The effect that the IPE experience had on } \\
\text { students becoming professionally proficient }\end{array}$ \\
\hline & & $\begin{array}{l}\text { Personal } \\
\text { development }\end{array}$ & $\begin{array}{l}\text { The effect, on a personal level, that the IPE } \\
\text { experience had on students as members of } \\
\text { the greater social construct }\end{array}$ \\
\hline & & $\begin{array}{l}\text { Community } \\
\text { response }\end{array}$ & $\begin{array}{l}\text { Attitudes and behaviour displayed by } \\
\text { community members when they interacted } \\
\text { with the students }\end{array}$ \\
\hline & & Expectations & $\begin{array}{l}\text { What both students and community } \\
\text { members aimed to achieve through the IPE } \\
\text { interaction }\end{array}$ \\
\hline & & $\begin{array}{l}\text { Community } \\
\text { perception }\end{array}$ & $\begin{array}{l}\text { Students' experiences and interpretation of } \\
\text { the way community members responded to } \\
\text { their presence }\end{array}$ \\
\hline
\end{tabular}




\begin{tabular}{|c|c|c|c|}
\hline Theme & Definition* & Category & Definitions \\
\hline & & Empathy & $\begin{array}{l}\text { Students personalising community and } \\
\text { community needs to such a degree that } \\
\text { they understand and share another } \\
\text { person's experiences and emotions }\end{array}$ \\
\hline & & Assumption & $\begin{array}{l}\text { Students' preconceived ideas of the } \\
\text { environment, community and IPE groups } \\
\text { they were going to interact with }\end{array}$ \\
\hline & & Facilitation & $\begin{array}{l}\text { The effect of supervision and reciprocal } \\
\text { community interaction on creation and } \\
\text { application of knowledge, competencies } \\
\text { and attitudes }\end{array}$ \\
\hline \multirow[t]{7}{*}{$\begin{array}{l}\text { Professional } \\
\text { socialisation }\end{array}$} & \multirow{7}{*}{$\begin{array}{l}\text { Weidman et al. (2001) } \\
\text { defines socialisation in } \\
\text { a broad sense as, "the } \\
\text { process by which } \\
\text { persons acquire the } \\
\text { knowledge, skills, and } \\
\text { disposition that makes } \\
\text { them more or less } \\
\text { effective members of } \\
\text { society" }\end{array}$} & $\begin{array}{l}\text { Collaborative } \\
\text { practice }\end{array}$ & $\begin{array}{l}\text { Student experiences of how } \\
\text { interprofessionality was achieved on the } \\
\text { IPE platform }\end{array}$ \\
\hline & & Common goals & $\begin{array}{l}\text { The interlinkage/alignment of the goals of } \\
\text { the different professions making up the } \\
\text { interprofessional groups and with that of } \\
\text { the community. }\end{array}$ \\
\hline & & Values & $\begin{array}{l}\text { Defines how the IPE experience affected } \\
\text { students and their perceptions of different } \\
\text { professions and the community/code of } \\
\text { behaviour, rule of conduct/moral standards }\end{array}$ \\
\hline & & Reflective practice & $\begin{array}{l}\text { Students observe and refine practice in } \\
\text { general on an ongoing basis - self, } \\
\text { practice, interprofessional collaboration } \\
\text { and community }\end{array}$ \\
\hline & & $\begin{array}{l}\text { Community } \\
\text { empowerment }\end{array}$ & $\begin{array}{l}\text { Addressing community needs and assisting } \\
\text { communities to help themselves; thereby } \\
\text { creating sustainability }\end{array}$ \\
\hline & & Achievement & $\begin{array}{l}\text { Students' perceptions of the impact of the } \\
\text { IPE and their personal involvement on the } \\
\text { community }\end{array}$ \\
\hline & & Key competency & $\begin{array}{l}\text { Students reflecting on IPE key } \\
\text { competencies identified for learning on a } \\
\text { collaborative rural platform }\end{array}$ \\
\hline
\end{tabular}

* Where necessary, the researchers formulated contextualised definitions.

From the information presented in Table 1 the most applicable categories related to the stated themes will be discussed in the sections below.

\section{Conceptual metaphors}

Students used conceptual metaphors to compare their week of IPE to taking a journey:

"Five students unknowingly begin their journey towards an unexpected life-changing experience."

Another group used fire as a conceptual metaphor to describe their IPE experience:

"The darkness quickly overwhelmed our spirit of warmth, but little did we know, a spark could be enough to set the world ablaze."

Water illustrated the creation of new relationships during their placement:

"Like the ripple effect through water, so travels the cascade of touching lives. Three physios, two nursing students and two medical students, strangers at first, were merged together to form a drop that fell in the Free State pond. And from Trompsburg quickly rippled to Springfontein." 


\section{Critical consciousness}

The categories under critical consciousness collectively validates the complex environment students found themselves in during their placements on the rural interprofessional learning platform. Statements related to transformation indicated that students embraced these complexities:

"We had to make use of our skill to be adaptable and flexible in unfamiliar environments."

Students also reflected on the challenges they faced as a team:

"Heading into the rural area for the diabetic home visits was an intimidating experience, as this was the first for many."

As a team, students believed that the challenging environment promoted personal development:

"As this week is ending, a few things would definitely live on forever. Knowledge, skills and, of course, everlasting friendships."

In addition to personal development, healthcare professionals also have to learn to understand patient circumstances, therefore empathy is considered essential for successful health outcomes:

"The screening at a secondary school opened our eyes to the needs of the learners. Physically, socially and psychologically. This challenged us, not to only relate as medical professionals, but as previous high school learners with similar problems and genuine empathy."

"We went from complaining about our supposed struggles to being stunned into silence by the hardships they experienced daily."

The above categories reflect experiences on the week's IPE placement. They also illustrate the changes students experienced in relation to their initial expectations:

"Combined, we were all sceptical of what the experience will entail. We each had our own presuppositions and stereotypes that we created about the community."

The aforementioned perspective change would not have been possible without facilitation, and students stated that:

"Trompsburg facilitators created opportunities for us to expand our knowledge, to be able to gain from integrated deep wealth of knowledge."

\section{Interprofessional socialisation}

Interprofessional socialisation includes categories with statements that inform how the experience influenced the way students perceived their own professional identity and that of 
other health disciplines making up the broader healthcare team. In this category, interprofessional practice was considered to be most important:

"As a team we discovered the importance of interprofessional practice in preparing us to relate to our future colleagues that would prevent the fragmentation of the healthcare system."

Common goals made collaborative practice possible:

"As they [students referring to themselves] opened the bag, they realised that they had one common goal, that is, to improve the lives of the community."

Having common goals and collaborating to achieve said goals as a healthcare team requires reflective practice:

"It appeared to us that small communities are the prime place for halting disease in early stages, and promoting health, in turn creating healthy communities."

Collaborating and using reflective practice to address community needs led to validation of actions and students' sense of achievement:

"We were able to detect healthcare problems in local learners, which may otherwise remained unnoticed or overlooked by local healthcare systems. This enabled us to make many crucial referrals to the healthcare professions at the clinic, thus improving health outcomes in the Trompsburg community."

When students address community needs, they not only experience a sense of achievement they also believe that the consequences of their actions lead to community empowerment:

"By empowering patients with knowledge in order for them to play a vital part in their own health and well-being."

The main objective of placing students on an rural learning platform was to improve interprofessional practice through the achievement of the previously endorsed key interprofessional competencies. The statement below is a summary by a student group that reflects on the role of facilitators and how facilitation empowered them with the tools needed to achieve the week's outcomes:

"The opportunities included role clarification, where each student informally took up the responsibility their profession had taught them. Next was teamwork, which we exercised with running in our free time. Using our garden to the best of our ability. Then came interprofessional communication, where we were asked to collaborate and to make a poster combining vital opinions. Lastly, on our fertiliser molecule was the community-centred approach we had to have during the screening of the locals, ensuring any referrals were not to be missed." 
Figure 1 presents the categories with the highest number of statements for the various themes identified; 13 of the statements reflect the key interprofessional competencies advocated for. Upon closer inspection and analysis of the statements in the categories presented in Figure 1, such as reflective practice, personal development and challenges, show the statements are related to the IPE key competency, addressing a person-centred approach $(f=43)$. Statements that reflect transformation, professional proficiency, collaboration, common goals and achievement lean towards the key competency, promoting team functioning $(f=87)$.

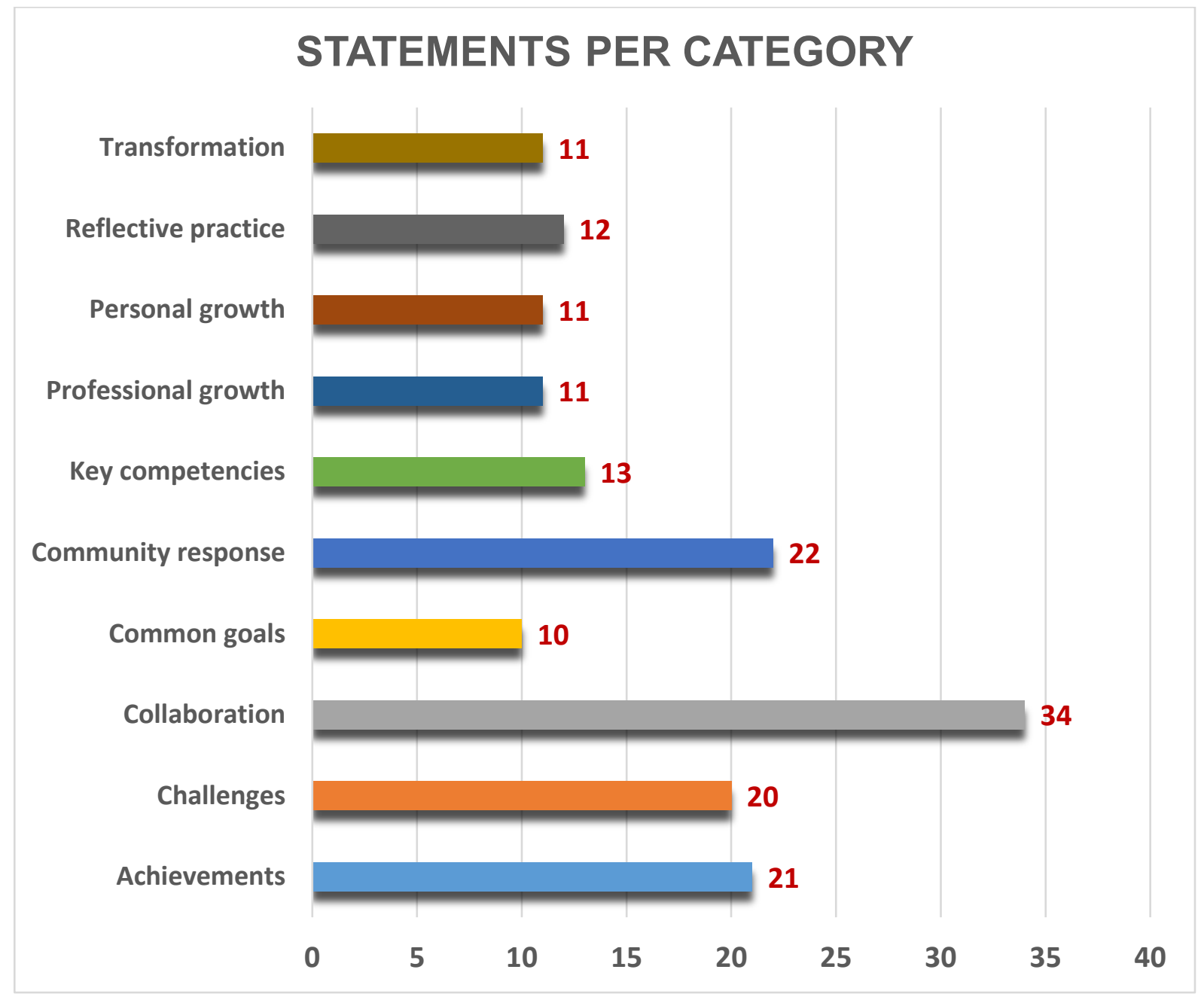

Figure 1: Categories with the highest number of statements

\section{DISCUSSION}

The three themes that emerged from the digital stories articulate the interprofessional experiences of groups of health professions students placed on an rural learning platform. Students who were exposed to a purposefully structured, complex environment expressed their experiences through conceptual metaphors; by making statements related to a critical consciousness; and by explaining how they found their place in the healthcare team through 
interprofessional socialisation.

The discussion includes those themes and categories that align best with the purpose of this study. As proposed by Creswell's analytical spiral step Number 7, the researchers selected these themes and categories. Step 7, that is, testing the emergent understandings, suggests that the researchers should determine the usefulness of the data (themes and categories) for answering the question (addressing the purpose) being asked (Creswell 1998).

Conceptual metaphor, in the context of this study, are indicative of ways of thinking and refers to the use of figurative expressions / symbolism and comparisons to explain the IPE experiences. Richardson and Grose (2009) defines metaphors and descriptive words as "emotional intensifiers", which provide a measure of the impact of an experience. Kok, Lim and Low (2011) states that metaphor is a form of poetic language capable of "linking cognitive and affective" learning. The categories underlying this theme represent the students' desire to use strong visual cues to illustrate their understanding, and the conceptual metaphors included a journey, setting the world ablaze, water on the parched land and solving a puzzle. The conceptual metaphors used by the different student groups also represents the diversity of metacognition that needed to take place for the achievement of the same triumph. Here, triumph denotes the achievement of learning and serving one's community. It therefore encapsulates the other two themes, of critical consciousness and interprofessional socialisation, which leads from social immersion, to social empathy, followed by social response and proactive social contribution, towards social justice for the collective good.

The second theme critical consciousness describes an individual's critical understanding of the world and how individual, social and political circumstances influence the understanding of one's reality. It involves fostering of a critical awareness of the self, others, and the world and a commitment to. Critical consciousness theorises that students could adapt to their reality, or integrate into it. Integration is the ability to adapt and transform one's reality by responding to challenges within one's environment. This is essential for creating an empathetic understanding of others, which students often find challenging. The findings of this study provide evidence of the empathetic learning experienced by students on this rural interprofessional learning platform.

Critical consciousness is achieved by incorporating images and narration as a trigger for reflection, evaluation and critical group dialogue, which enhances self-esteem and the development of critical thinking. Students' narrations enabled them to communicate their doubts, certainties and predictions, and can therefore be described as an epistemic modality of social consciousness. From the students' digital stories, critical consciousness revealed the following categories: transformation, personal development, community response and 
empathy. Students see the value of incorporating patient preferences, and they realise how it contributes to what is referred to as high-value healthcare (Elsevier 12/2013).

Students' feedback showed that they became aware of social, health and cultural issues of an assigned community, and similar communities to whom they will provide healthcare. Through the IPE programme, students realised that, when patients and communities assume greater responsibility for factors influencing their health, the value of healthcare is enhanced. The connection between health and poverty is reciprocal - poor health outcomes lead to decreased economic productivity, which lowers economic power, which leads to people being unable to invest in their own healthcare (Adena and Myck 2014). Immersing students in an rural interprofessional learning platform enabled students to make the connection between health outcomes and the social determinants of health. In a study by MacDonnell, George and Misto (2012) IPE was facilitated through case-based work, and students were not exposed to a community. Students from different disciplines displayed a greater understanding of each other's (discipline) knowledge and skills; however, context and application using a case-based approach to IPE could be questioned.

The third theme is interprofessional socialisation. The process of professional socialisation suggests that individual professions already presents a powerful structural reality. Students are considered newcomers who are being moulded into what the specific profession regards as "good" professionals (Stacey and Hardy 2011). On this interprofessional platform this mould is being challenged and reshaped to reflect the structural realities and interdependency of an interprofessional healthcare team. In an article entitled, Challenging the shock of reality through digital storytelling, Stacey and Hardy (2011) used thematic content analysis, which involved identifying common views and perspectives expressed by the participants in their study. The opportunity for reflection and creative consideration, from contextual border crossing to dissonance, personalising, and, eventually, connecting learning, might enable the student to cope in similar situations. From these student digital story reflections, the researchers reported the emergence of a new model of learning called the Spiral of Growth Through Stories, which is not only extrapolated from, but also extends Kolb's learning cycle (Kolb 1984). Stacey and Hardy's model recognises that the potential for growth and learning extends beyond the individual student learner to a community of students, facilitators, preceptors and other audiences, thereby, initiating further cycles of learning.

In a study by Paliadelis and Wood (2016) that used digital stories, students identified a range of ethical, professional and political issues they encountered in their reflections. Similarly, categories found in the current study included values, professional proficiency and community empowerment. In Paliadelis and Wood's study a major theme was understanding 
workplace complexity. Health professions students placed on an rural learning platform students demonstrated this by achieving the endorsed interprofessional competencies. Interprofessional socialisation through IPE assists in maintaining and enhancing the professional identity of various professions. This is achieved because students are more familiar with their own roles and the roles and responsibilities of others.

Although the purpose was to describe if health professions students' developed key competencies such as role and value clarification, person-centred care, team functioning and interprofessional communication, the feedback from students surpassed the stated purpose. The three themes, namely conceptual metaphors, critical consciousness and interprofessional socialisation that were identified introduce an extended achievement that stems from the complexities associated with their experiences.

In this description of learning on an rural interprofessional platform, students were requested to create digital stories of their experiences. Using digital stories as a measuring instrument for students' experiences and achievement is validated by the themes and categories uncovered. When compared to a more formal measuring instrument, such as the Interprofessional Collaborative Competency Attainment Survey, developed by the Canadian Interprofessional Health Collaborative (Schwindt et al. 2017), the themes and categories of this study articulate with the 20 items of the ICCAS assessment of self-reported competencies.

Kirkpatrick and Kirkpatrick's (2009) four levels of outcomes aims to grade the degree of success of a learning programme; success relates to learning and whether the learning experience was favourable. The four levels are reaction, learning, behaviour and findings, and each outcome builds progressively on the next. The themes and categories of the current study are an indication of the learning that took place, and the nature and content of the narrations indicate that students valued and enjoyed the placement on an rural interprofessional learning platform.

\section{CONCLUSION}

Digital stories based on students' interprofessional experiences, as a methodology, contributed to the researchers' understanding of students' learning on an rural platform, and enabled the Faculty of Health Sciences to refine its interprofessional education programme. Importantly, the findings confirmed the premise that a defined IPE programme that includes cautiously selected activities develops key interprofessional competencies. In a South African context, developing these key interprofessional competencies aligns with the national vision to improve healthcare outcomes.

This study did not aim to address the degree to which students apply what they learned 
during training when they are qualified practitioners (Kirkpatrick Level 3: behaviour), or level 4 of the Kirkpatrick four levels of outcomes, which asks to what degree targeted outcomes occur as a result of the learning event(s) and its subsequent reinforcement. Further research to address Kirkpatrick's Level 3 and 4 is recommended.

Ultimately the question is whether interprofessional education nested in an rural learning platform can remedy traditional instruction which does not always prepare students sufficiently for the world of work.

\section{ACKNOWLEDGEMENTS}

This work was funded by the School of Nursing at the University of the Free State, the National Research Foundation and the Clinical Training Grant of the Department of Education.

\section{REFERENCES}

Adena, M. and M. Myck. 2014. Poverty and transitions in health in later life. Social Science \& Medicine 116: $202-210$

Anderson, E. S. and D. Kinnair. 2016. Integrating the assessment of interprofessional education into the health care curriculum. Journal of Taibah University Medical Sciences 11(6): 552-558.

Brashers, V., E. Phillips, J. Malpass and J. Owen. 2015. Review: Measuring the impact of interprofessional education (IPE) on collaborative practice and patient outcome. December. https//www.ncbi.nlm.nih.gov/books/NBK338366/ (Accessed 15 September 2017).

Cox, M., P. Cuff, B. Brandt, S. Reeves and B. Zieler. 2016. Measuring the impact of interprofessional education on collaborative practice and patient outcomes. Journal of Interprofessional Care 2016 30(1): 1-3. http://dex.DOI: 10.3109/13561820.2015.1111052. http://dx.doi.org/10.31209/13561 820.2015.1111052 (Accessed 15 September 2017).

Creswell, J. W. 1998. Qualitative inquiry and research design, choosing among five traditions. Thousand Oaks: Sage publications.

Creswell, J. W. 2014. Research design. Qualitative, quantitative and mixed methods approaches. $4^{\text {th }}$ Edition. Los Angeles: Sage publications.

D'Amour, D., M. Ferrada-Videla, L. S. Rodriguez and M-D. Beaulieu. 2005. The conceptual basis for interprofessional collaboration: Core concepts and theoretical frameworks. Journal of Interprofessional Care 19(Sup1): 116-131. http://www.tandfonline.com/doi/abs/10.1080/ 13561820500082528 (Accessed 7 September 2017).

De Castro Barbosa Mello, C., R. O. Alves and S. M. A. Lemos. 2015. Methods of health education and training: literature review. Revista CEFAC, 16(6). http://dx.doi.org/10.1590/1982-0216 201416012 (Accessed 7 September 2017).

Department of Health. 2017. Republic of South Africa White Paper. National health insurance, Towards universal health coverage. Pretoria: Government Printers.

DoH see Department of Health.

Du Plooy-Cilliers, F., C. Davis and R-M. Bezuidenhout. 2014. Research matters. Cape Town: Juta \& Company Ltd.

Elsevier. 12/2013. Interprofessional collaborative practice in healthcare: Getting prepared, preparing to succeed. Website. (Accessed 7 September 2017).

Fish, T., G. Lourens, L. Meyer, J. Muller and H. Conradie. 2015. When the clinic is not yet built ... the 
Avain Park Service Learning Centre story. AJHPE African Journal of Health Professions Educationalists May 7(1) Suppl 1.

Flack, S. 2011. Interprofessional education in the Faculty of Health Sciences at University of KwaZuluNatal. Conference Paper, European Interprofessional Network (EIPEN), September. https://www.researchgate.net/publication/263973225 Interprofessionan Education in the Faculty_of_Health_Sciences_at_University_of_KwaZ̄ulu-Natal (Accessed 2 November 2017).

Green, M. R. and M. L. Walters. n.d. Storytelling: From oral to digital. Presented by Public Partnership \& Outreach, Office of the Provost and the College of Education, Department of Teaching, Learning, and Culture at Texas A\&M University Workshop.

Hartman, N., H. Kathard, G. Perez, S. Reid, J. Iriam, G. Gunston, V. Janse van Rensburg, V. Burch, M. Duncan, D. Hellenberg, I. Van Rooyen, M. Smouse, C. Sikana and E. Badenhorst. 2012. Health Sciences undergraduate education at the University of Cape Town: A story of transformation. SAMJ The South African Medical Journal Leading research impacting clinical care in Africa 102(6). http://www.samj.org.za/index.php/samj/article/view/5680/4230 (Accessed September 2017).

John Hopkins School of Nursing. 2013. Daniels IPE Scholars Program. http://nursing.jhu.edu/ excellence/interprofessional/initiative.html (Accessed 8 September 2017). Lambert J. Digital storytelling: Capturing lives, creating community. 4th ed. New York: Routledge.

Kok, J. K., C. M. Lim and S. K. Low. 2011. Attending to metaphor in counselling. International Conference on Social Science and Humanity, IPEDR 5: 54-58.

Kolb, D. A. 1984. Experiential learning: Experience as the source of learning and development. New Jersey: Prentice-Hall.

Kirkpatrick, J. and W. Kirkpatrick. 2009. The Kirkpatrick four levels ${ }^{\mathrm{TM}}$ : A fresh look after 50 years. 1959-2009, April. http://www.kirkpatrickpartners.com/Portals/0/Resources/Kirkpatrick\%20Four \%20Levels\%20white\%20paper.pdf (Accessed 15 November 2017).

Lambert, J. 2013. Digital storytelling: Capturing lives, creating community. $4^{\text {th }}$ Edition. New York: Routledge.

MacDonnell, C. P., P. George and K. Misto. 2012. Rhode Island's interprofessional education initiatives. Medicine \& Health/Rhode Island September 95(9): 277-278.

Mahboobeh, K. M, A. Soleiman, K. S. A. Seyyed and B. Shoaleh. 2016. Interprofessional education in the integrated medical education and health care system: A content analysis. Journal of Advances in Medical Education \& Professionalism July 4(3): 103-110.

Nelson Mandela University. n.d. New developments. http://www.newname.mandela.ac.za/Ourstory/New-developments (Accessed 8 November 2017).

NMU see Nelson Mandela University.

Paliadelis, P. and P. Wood. 2016. Learning from clinical placement experience: Analysing nursing students' final reflections in a digital storytelling activity. Nurse Education in Practice 20(September): $39-44$.

Ratka, A., J. A. Zorek and S. M. Meyer. 2017. Overview of Faculty development programs for interprofessional education. American Journal of Pharmaceutical Education 81(5): Article 96.

Reeves, S. 2016. Why we need interprofessional education to improve the delivery of safe and effective care. 20(56): 185-96. http://dx.DOI:10.1590/1807-57622014.0092

Reeves, S., J. Goldman and I. Oandasan. 2007. Key factors in planning and implementing interprofessional education in health care settings. Journal of Allied Health 36(4): 231-235.

Richardson, J. and J. Grose. 2009. The use of descriptive words and metaphor in patient and carer experience of palliative day care: Secondary analysis of a qualitative study. The Open Nursing Journal 3: 18-24.

Schwindt, R., J. Agley, A. M. McNelis, K. S. Hudmon, K. Lay and M. Bentley. 2017. Assessing perceptions of interprofessional education and collaboration among graduate health professions 
students using the Interprofessional Collaborative Competency Attainment Survey (ICCAS). Journal of Interprofessional Education \& Practice 8(September): 23-27.

Sevin, A. M., K. M. Hale, N. V. Brown and J. W. McAuley. 2016. Instructional design and assessment. Assessing interprofessional education collaborative competencies in service-learning course. American Journal of Pharmaceutical Education 80(2): Article 32.

SAAHE see South African Association of Health Education.

South African Association of Health Education. 2017. Consensus statement: Decentralised training in the health professions. Adopted on the SAAHE National Conference July 2017. Potchefstroom, North West province.

Stacey, G. and P. Hardy. 2011. Challenging the shock of reality through digital storytelling. Nurse Education in Practice 11: 159-164.

Thistlethwaite, J. 2012. Interprofessional education: A review of context, learning and the research agenda. Medical Education 46: 58-70. http://dex.DOI:10.1111/j.365-2923.2011.04143.x

Treadwell, I. and H. S. Havenga. 2013. Ten key elements for implementing interprofessional learning in clinical simulations. African Journal of Health Professions Education 5(2): http://www.ajhpe.org.za/index.php/ajhpe/rt/printerFriendly/233/186 (Accessed 28 September 2017).

University of Toronto. n.d. Interprofessional Education Curriculum. Toronto: Centre for Interprofessional Education.

Van Wyk, H. 2017. Interprofessional education programme to develop teamwork among undergraduate healthcare students during community fieldwork. Available on http://hdl.handle.net/2263/53052 (Accessed 5 October).

Weidman, J. C., D. J. Twal and E. L. Stein. 2001. Socialization of graduate and professional students in higher education: A perilous passage? ASHE-ERIC Higher Education Report, 28. San Francisco: Jossey-Bass.

World Health Organization. 2010. Framework for action on interprofessional education ND Collaborative Practice. Geneva: WHO Press, World Health Organization. 